\title{
Estudo farmacognóstico do caule e raízes de Microgramma squamulosa (Kaulf.) Sota (Polypodiaceae)
}

\author{
Ivana B. Suffredini, ${ }^{* 1}$ Elfriede M. Bacchi, ${ }^{2}$ Jane E. Kraus ${ }^{3}$ \\ ${ }^{1}$ Laboratório de Extração, Universidade Paulista, UNIP, Av. Paulista, 900, $1^{\circ}$ andar, 01310-100 São Paulo-SP, \\ Brasil, \\ ${ }^{2}$ Departamento de Farmácia, Faculdade de Ciências Farmacêuticas, Universidade de São Paulo, Av. Lineu \\ Prestes, 580, 05508-900 São Paulo-SP, Brasil, \\ ${ }^{3}$ Departamento de Botânica, Instituto de Biociências, Universidade de São Paulo, R. do Matão Trav. 14, 321, \\ 05508-900 São Paulo-SP, Brasil
}

\begin{abstract}
RESUMO: Microgramma squamulosa (Polypodiaceae) tem sido tradicionalmente empregada como agente contra úlceras estomacais. Trabalhos realizados anteriormente confirmaram a atividade antiúlcera do extrato bruto de caule/raízes e de suas frações preparadas com os caules e as raízes dessa planta. Foi também demonstrado que o extrato não é tóxico no modelo de toxicidade aguda, em ratos. Devido a esses resultados, considerou-se importante providenciar instrumentos capazes de orientar a caracterização da droga vegetal. M. squamulosa é uma epífita com caule escandente, portando folhas na porção adaxial e raízes adventícias na porção abaxial. As principais características histológicas para identificação são: escamas lanceoladas, peltadas e com tricomas, esclereídes, meristelos (feixes anficrivais) e traqueídes com espessamento espiralado no caule; pêlos em fita e esclereídes, na raiz. A análise fitoquímica e o perfil cromatográfico realizados com o extrato bruto de caule/raízes e frações ativas mostraram a presença de flavonóides e taninos, que podem estar relacionados à atividade antiúlcera. Os resultados obtidos auxiliam a identificação da planta e possibilitam a caracterização da droga vegetal fragmentada e também sob forma de pó ou extrato.
\end{abstract}

Unitermos: Microgramma squamulosa, erva silvina, samambaia, epífita, morfo-histologia, flavonóides, taninos.

\begin{abstract}
Pharmacognostic and phytochemical study of the stem and roots from Microgramma squamulosa (Kaulf.) Sota (Polypodiaceae)". Pharmacognostic and phytochemical study of the stem and root of Microgramma squamulosa (Kaulf.) Sota. Erva silvina, or Microgramma squamulosa (Kaulf.) Sota belongs to the family Polypodiaceae and is traditionally used as an antiulcer agent. Previous assays showed results that confirm the antiulcer action of the ethanolic extract and some fractions of the stem of M. squamulosa and results showing no significant toxicity in the acute model, both made in rats. Due to the significant results obtained in this previous work, it becomes important to furnish tools to identify the vegetal drug. The species is an epiphyte that bears lanceolate scales totally covering the long-creeping brown-colored stem. Adventicious roots can be seen in the abaxial portion of the stem, while the leaves appear in the adaxial portion. Elements which contribute to the histological identification are: peltate lanceolate -haired scales, sclereids, meristeles (amphicribal bundles) and scalariform tracheids in the stem; strip hairs and sclereids in the roots. Phytochemical screening and TLC analysis showed the presence of flavonoids and tannins which may be related to the antiulcer activity. Results shown may help the identification of the plant as well as the characterization of the fragmented vegetal drug and if it is presented as powder or as extract.
\end{abstract}

Keywords: Microgramma squamulosa, erva-silvina, fern, epiphyte, morpho-hystology, flavonoids, tannins.

\section{INTRODUÇ̃̃O}

De longa data as pteridófitas vêm sendo utilizadas popularmente como remédio (Banerjee \& Sen, 1980; Gaur \& Bhatt, 1994) na forma de infusos (Ortega \& Diaz, 1993), decoctos (Caula et al., 1990), pastas, cataplasmas, loções (Ortega \& Diaz, 1993) e também como bebidas e alimento (Jones, 1987).
Estudos químicos com samambaias e espécies afins foram realizados por diversos autores (Arai et al., 1992; Imperato, 1990; Camps et al., 1990; Marco et al., 1993, Zhou et al., 1998; Tsuzuki et al., 2001; Huang et al., 2003), bem como estudos farmacológicos (Suffredini et al., 1999; Bresciani et al., 2003).

Erva silvina é o nome comum de Microgramma squamulosa (Polypodiaceae). Segundo Ogura (1972), 
as Polypodiaceae estão distribuídas por todo o mundo, com mais de 100 espécies. Microgramma é um gênero americano com aproximadamente 13 espécies, ocorrendo na região tropical desde o sudeste da Flórida até a Argentina (Buenos Aires); o centro de diversidade do gênero localiza-se do leste das inclinações dos Andes até as adjacências da Bacia Amazônica, onde ocorrem 10 espécies (Tryon \& Tryon, 1982).

M. squamulosa é popularmente utilizada contra úlcera. Suffredini et al. (1999) demonstraram uma significativa atividade antiúlcera em ratos, no modelo induzido por ácido acético, frente à cimetidina. Nesse mesmo trabalho, os autores não verificaram toxicidade aguda, em ratos. Baseado nesses resultados, propôsse caracterizar a droga vegetal constituída pelo caule e raízes de M. squamulosa, por meio de sua descrição morfológica e anatômica e analisar o extrato vegetal, obtendo-se a identificação genérica dos grupos de substâncias ativas, bem como seu perfil cromatográfico e o de suas frações.

\section{MATERIAL E MÉTODOS}

\section{Coleta da planta}

Microgramma squamulosa (Kaulf.) Sota (Polypodiaceae) foi coletada na região do Butantã, cidade de São Paulo (SP), no mês de abril de 1993. A exsicata, depositada no Herbário UNIP sob número UNIP 5438 e número de coleta SAF 21 foi comparada com material similar, de número SP-701, da coleção do Herbário SP, tendo sido identificada e comparada pelo Dr. Jefferson Praddo, do Instituto de Botânica, São Paulo, SP.

\section{Estudo morfológico e anatômico}

A descrição geral da planta foi feita com base na análise de materiais recém coletados e em comparação com o herborizado (exsicata SP-701).

Neste trabalho, o estudo morfo-histológico foi delineado a ser feito tanto com o caule como com as raízes da planta, devido ao fato de que as raízes de M. squamulosa são adventícias e estão intimamente ligadas ao caule. Material recém coletado foi utilizado no estudo.

\section{Cortes histológicos}

Fragmentos de caules ou raízes foram inseridos entre porções de isopor e com auxílio de lâmina de barbear foram feitos cortes histológicos manuais (Oliveira et al., 1991). Do caule adulto foram obtidos cortes transversais e longitudinais e das raízes mais desenvolvidas, cortes transversais. Os cortes histológicos, independentes de sua origem, foram corados com azul de astra (C.I. não indicado) ou azul de alcian 8 GX (C.I. 74240), ambos $0,5 \%$ em ácido tartárico $2 \%$, e fucsina básica (C.I.
42510) $0,5 \%$ em etanol $50 \%$, segundo metodologia descrita por Kraus et al. (1998). As lâminas contendo cortes histológicos foram montadas com glicerina 50\% ou gelatina glicerinada de Kaiser (Kraus \& Arduin, 1997); ambas as preparações histológicas foram vedadas com esmalte incolor para unhas.

\section{Tecidos dissociados}

Para a dissociação dos tecidos do caule e das raízes foram empregados os métodos de Jeffrey (Jeffrey, 1917) ou de Franklin (1945, modificado segundo Kraus e Arduin, 1997). O frasco contendo material dissociado foi previamente agitado antes da retirada da alíquota usada no preparo da lâmina. Para cada material foram preparadas 10 a 25 lâminas, visando uma boa amostragem. A montagem das lâminas foi feita conforme o procedimento descrito para os cortes histológicos.

\section{Obtenção do extrato bruto de caule/raízes e suas frações e do extrato bruto de folhas}

Caules/raízes e folhas recém coletados foram secos em estufa com circulação de ar a $40{ }^{\circ} \mathrm{C}$ por três dias (Oliveira et al., 1991). O material seco foi moído em moinho de martelo e passado por tamis de um mm. O extrato de caules/raízes foi preparado com 3096,5 $\mathrm{g}$ do pó do material botânico, segundo o método A da Farmacopéia dos Estados Unidos do Brasil (1959). O pó foi umedecido com o líquido extrator, etanol $70 \%$, e acondicionado num percolador de aço inoxidável de tamanho adequado, permanecendo em maceração por 12 horas. A velocidade de percolação foi de 80 gotas por minuto. A droga foi percolada até esgotamento total. $\mathrm{O}$ álcool do percolado foi evaporado à pressão reduzida e temperatura limite de $60{ }^{\circ} \mathrm{C}$. A água residual foi liofilizada e o extrato bruto de caule/raízes resultante utilizado na triagem fitoquímica e análise cromatográfica. O rendimento do extrato de caule/raízes foi de $383,3 \mathrm{~g}$, ou $12,4 \%$, e apresentou coloração marrom-esverdeada, odor característico e desagradável e sabor adstringente. De modo similar, extrato da folha foi feito empregandose a mesma técnica descrita para o extrato de caule/ raízes, utilizando-se $1585,0 \mathrm{~g}$ de folhas. O rendimento obtido foi de 169,6 g, ou 17,0 \%, apresentou coloração marrom-avermelhada, odor característico e sabor adstringente.

As frações foram obtidas a partir de $50 \mathrm{~g}$ do extrato bruto de caule/raízes liofilizado, que foi colocado em um béquer e ao qual foi adicionado 1 litro de clorofórmio. O conjunto foi colocado sob agitação por 30 minutos à temperatura ambiente, e posteriormente foi filtrado com papel filtro. O material sólido restante no papel filtro foi colocado em um novo béquer, ao qual se adicionou 11 de acetato de etila. $\mathrm{O}$ conjunto foi colocado sob agitação e filtrado como no passo anterior. Este procedimento foi repetido para os outros 
solventes, usados subseqüentemente segundo a ordem de polaridade crescente. Os solventes foram evaporados a baixa pressão e armazenados em geladeira até o uso.

\section{Triagem fitoquímica e perfil cromatográfico}

A droga vegetal em pó, formada por caule e raízes foi analisada quanto à presença de glicosídeos cardioativos, flavonoídicos e, antraquinônicos, alcalóides, gomas e mucilagens (Witchl, 1971), glicosídeos saponínicos, taninos e óleos essenciais (Costa, 1972).

O perfil cromatográfico foi obtido a partir do extrato bruto de caule/raízes liofilizado do caule e suas frações clorofórmio, acetato de etila, etanol e etanol $50 \%$ e do extrato bruto de folhas. Quercetina, apigenina e canferol foram empregadas como substâncias de referência. As análises cromatográficas em camada delgada (CCD) foram realizadas em placas de sílica gel GF (Merck ${ }^{\circledR}$ ), de $20 \times 20 \mathrm{~cm}$, com 0,2 mm de espessura, ativação a $110^{\circ} \mathrm{C}$ por $1 \mathrm{~h}$, cinco toques para a adição da amostra e percurso de $10 \mathrm{~cm}$ com sentido ascendente. A revelação foi feita com difenilboriloxietilamina $1 \%$ em metanol, seguido de carbowax $400 \quad 5 \%$ em metanol e visualização em UV 366nm (Wagner \& Bladt, 1996). As fases móveis empregadas (v/v) foram: (1) clorofórmio: acetona:ácido fórmico $(85: 8: 8,5)$; (2) acetato de etila:ácido acético glacial:ácido fórmico:água (100:11:11:26); (3) clorofórmio:acetona:ácido fórmico (75:16,5: 8,5) (Wagner \& Bladt, 1996).

\section{RESULTADOS E DISCUSSÃO}

$\mathrm{Na}$ manufatura de fitoterápicos, a droga vegetal pode ser utilizada sob diversas formas, como pó ou extratos. Independente da forma a ser utilizada, a identificação da planta é necessária, visando à obtenção do material correto. Para tanto, o conhecimento das características morfológicas são de grande valia, pois plantas diferentes podem ter a mesma denominação popular ou apresentar grande semelhança com as de outra espécie, e na análise de drogas vegetais passa a ter uma elevada importância no auxílio de diagnose de drogas constituídas por órgãos vegetais fragmentados ou em pó. Com esse intuito, foi feita a descrição morfohistológica da droga vegetal constituída por caule e raízes de $M$. squamulosa, a qual foi baseada nos trabalhos de Sota (1960), Sehnem (1970), Tryon \& Tryon (1982) e Oliveira et al. (1991) e nas observações realizadas.

Trata-se de uma epífita (Figura 1A) com caule escandente, longo, ramificado, de coloração marrom, achatado dorso-ventralmente, com raízes localizadas na porção abaxial e folhas (frondes) na porção adaxial, recoberto por diversas escamas lanceoladas e peltadas (Figura 1B). Escamas presentes na superfície adaxial e também em parte da porção abaxial do caule, de castanhoclaras a castanho-escuras, no decorrer do tempo. Folhas dimorfas. Pecíolos com 1/2 a 1/4 do tamanho da lâmina, alados, superfície lisa, com algumas escamas; lâminas estéreis com formato elíptico, base cuneada, ápice acuminado, margem inteira, consistência cartácea, com poucas escamas na face abaxial, nervuras anastomosadas e distribuídas de maneira característica, formando duas séries de aréolas entre a margem e a costa; lâminas férteis com formato elíptico-alongado, base cuneada, ápice acuminado, margem levemente sinuada, consistência cartácea, possuindo escamas na costa abaxial e poucas na adaxial, nervuras anastomosadas, formando uma série de aréolas entre a margem e a costa, sendo mais estreitas que as estéreis; escamas da lâmina menores que as escamas do caule, castanho-claras, em vista frontal, mostraram-se em formato lanceolado. Na escama, as bordas das porções apical e mediana apresentavam tricomas, pluricelulares e unisseriados; na porção basal, observou-se a região de inserção do pé, localizada medianamente. Cada escama constitui-se por células com formato e tamanho variados, alongadas no sentido ápice-base e com paredes retas; na região marginal, suas células são menores e com paredes onduladas.

Soros no interior das aréolas, alimentados por duas vênulas, formando uma série de cada lado da costa, sendo que nos terços superior e inferior dispostos intercalados e no terço médio dispostos lado a lado, sem indúsio; esporos elipsoidais-monoletes. Raízes adventícias, finas, relativamente curtas, ramificadas e de coloração marrom escuro.

No presente trabalho, optou-se por usar o termo caule ao invés de rizoma, pois a denominação rizoma deve ser aplicada para a metamorfose caulinar devido à sua adaptação ao ambiente subterrâneo (Font Quer, 1979), e M. squamulosa é epífita, com estrutura caulinar visível. O termo fronde é sinônimo de folha, sendo bastante empregado para esse órgão das pteridófitas (Font Quer, 1979; J. Praddo, com. pess.), entretanto, outros autores preferem usar a designação folha (Joly, 1966; Raven, et al., 2001), pois o termo fronde pode trazer dúvidas para o não especialista em botânica e por ter outras conotações.

Dentre as principais características morfológicas que auxiliam a caracterizar a droga vegetal constituída pelo caule e pelas raízes de M. squamulosa podem ser citadas: caules com achatamento dorsoventral, folhas dimorfas, soros localizados no interior das aréolas das folhas férteis servidos por duas vênulas e presença de esporos elipsoidais. As escamas são lanceoladas, peltadas, em grande quantidade no caule e esparsas, menores, nas folhas.

A estrutura histológica do caule foi descrita por Kraus et al. (1993), entretanto, a descrição foi voltada para o desenvolvimento de uma galha caulinar, dificultando a obtenção das informações ora apresentadas. Salienta-se que Kraus et al. (l.c.) não avaliaram os tecidos caulinares dissociados, que possibilitam a análise da droga vegetal sob forma de pó. 
O caule, em corte transversal, apresentou formato circular a elíptico. A epiderme mostra-se uniestratificada com células, em geral, quadrangulares, com paredes primárias e recobertas por cutícula (Figuras 2.1A, 2.1B). Entre as células epidérmicas comuns encontram-se inseridas escamas peltadas. Estas, na porção das alas são formadas por uma camada de células e na porção do pé, por 3 a 4 camadas (Figura 2.1B). Sob a epiderme são observadas cerca de 13 a 20 camadas de células parenquimáticas (Figura 2.1A) de formato de arredondado a poligonal, com paredes primárias e vacúolo grande, contendo cloroplastos e amiloplastos; estas células são maiores que as epidérmicas. Na região subseqüente, 4 a 7 meristelos (Figura 2.1A) dispõem-se em arranjo elíptico. Cada meristelo apresenta formato elíptico (Figura 2.2A) ou circular e é geralmente circundado por 1 camada de esclereídes, de coloração castanho-avermelhada. Essas células têm formato quadrangular, com as paredes secundárias anticlinais e a periclinal interna espessadas (espessamento em U), e com pontoações simples bem evidentes. Após a camada esclerificada, encontra-se presente a endoderme (Figura 2.2B), cujas células são retangulares com o maior eixo tangencialmente disposto e com paredes primárias evidenciando estrias de Caspary; algumas células apresentam conteúdo celular amarelo-acastanhado. O periciclo, camada situada depois da endoderme, é uni ou biestratificado, com células maiores que suas vizinhas e de formato poligonal. Internamente ao periciclo localizam-se os tecidos vasculares, constituídos por floema e xilema. No floema, as células condutoras estão intercaladas com as parenquimáticas e se dispõem ao redor do xilema, que ocupa a porção mediana (feixe anficrival). O metaxilema dispõe-se entre os dois pólos de protoxilema, localizados junto ao periciclo (Figura 2.2A). Na região central do caule observa-se a medula, formada por células parenquimáticas (Figura 2.2C) similares às da região cortical. Corte longitudinal do caule na região do meristelo mostra a endoderme, o periciclo, as células crivadas e as traqueídes com espessamento de parede escalariforme (Figura 2.1B e Figura 2.2D).

Nos tecidos dissociados do caule observa-se a epiderme em vista frontal, com células poligonais; as células epidérmicas mostram arranjo circular na região de inserção da escama (Figura 2.1C). Entre os diversos elementos celulares destacam-se as células parenquimáticas, esclereídes, traqueídes escalariformes (Figuras 3.2A, 3.2B e 3.2C) e células crivadas com áreas crivadas (Figura 3.2D); as esclereídes são bastante freqüentes (Figura 3.2E).

A raiz, em corte transversal, apresenta formato circular, com muitos pêlos alongados, em forma de fita (Figura 3.1A). A epiderme é uniestratificada, com células retangulares e paredes primárias (Figura 3.1B); os pêlos inserem-se entre as células epidérmicas comuns. Abaixo da epiderme são observadas 3 a 4 camadas de células parenquimáticas com paredes primárias (Figura 3.1B). Após o parênquima, estão presentes 4 a 5 camadas de esclereídes, de formato retangular ou poligonal, com paredes bastante espessadas e com lume pequeno (Figuras 3.1B, 3.1C e 3.1D). A endoderme situada internamente ao esclerênquima é formada por 1 camada de células (Figura 3.1B e 3.1D). O periciclo, camada subseqüente era constituído por células de formato variado (Fig. 3.1D). Algumas células do parênquima, da endoderme e do periciclo apresentam conteúdo (Figuras 3.1B e 3.1D). Internamente ao periciclo, dois pólos de protoxilema podem ser observados e entre eles, dois elementos de metaxilema; o floema dispõe-se lateralmente ao xilema. Células do parênquima vascular intercalavam-se entre os poucos elementos condutores (Figuras 3.1D e 3.1E).

$\mathrm{Na}$ raiz dissociada são observados numerosos pêlos em forma de fita (não mostrado), células parenquimáticas com numerosos campos de pontoação e esclereídes (Figuras 3.1E e 3.1F).

Em M. squamulosa, o estelo é do tipo dictiostelo e cada meristelo é constituído por um feixe anficrival, com xilema centralmente disposto e circundado por floema. Segundo Fahn (1982), esse tipo de estelo é freqüente em várias pteridófitas. A presença de traqueídes com espessamento espiralado e de células crivadas também foram relatados em outras pteridófitas. Assim, a presença de meristelos, esclereídes e traqueídes (Figura 3.2C) são características importantes na caracterização do caule de M. squamulosa, principalmente quando sob a forma de pó. A estrutura radicular, apesar de pouco representativa na droga estudada também mostrou características relevantes para a caracterização da droga, como a presença de pêlos em forma de fita e esclereídes típicas.

Vale ressaltar que as escamas têm valor diagnóstico em nível específico e/ou genérico nas pteridófitas. Em M. squamulosa, as escamas são lanceoladas, peltadas e com tricomas, ocorrendo em grande quantidade no caule, embora estejam presentes

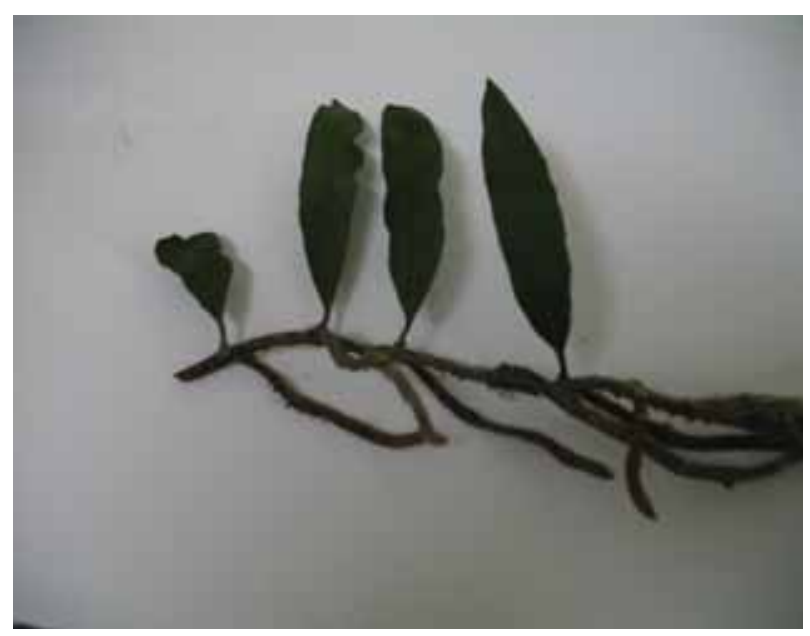

Figura 1. A) Microgramma squamulosa (Kaulf.) Sota. 

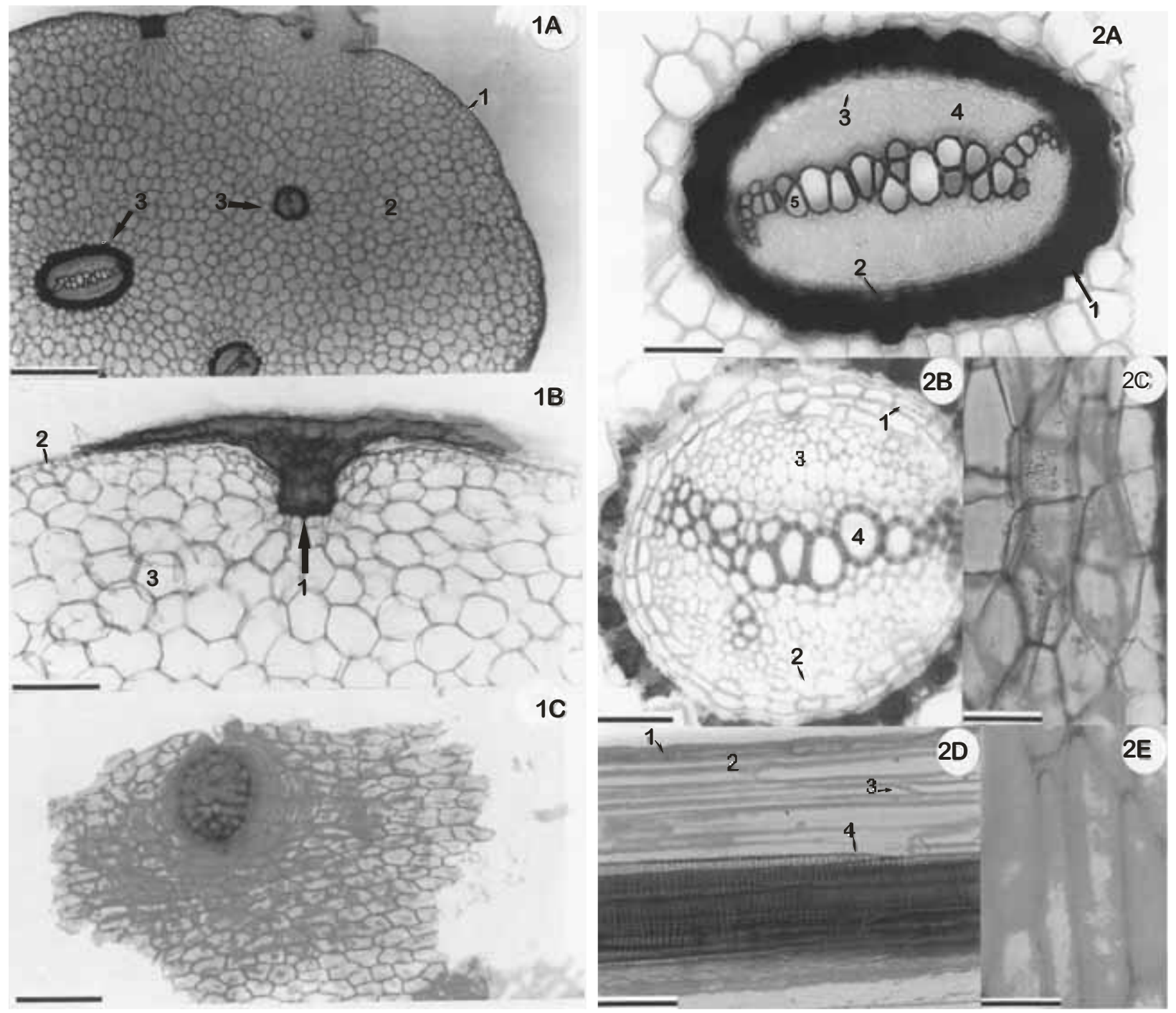

Figura 2. 1A) Barra $=500 \mu \mathrm{m}$. Corte transversal do caule visão geral. 1. epiderme, 2. parênquima, 3. feixes vasculares. $1 \mathrm{~B}) \mathrm{Barra}=200 \mu \mathrm{m}$. Corte transversal de caule. 1. inserção da escama, 2. epiderme, 3. parênquima. 1C) Barra $=200 \mu \mathrm{m}$. Vista frontal da epiderme do caule, inserção da escama. 2A) Barra $=200 \mu \mathrm{m}$.. Corte transversal de caule. 1. esclerênquima, 2. endoderme, 3. periciclo, 4. floema, 5. xilema. 2B) Barra $=100 \mu \mathrm{m}$. Corte transversal do caule. 1. endoderme com estrias de Caspary, 2. periciclo, 3. floema, 4. xilema. 2C) Barra=100 $\mu \mathrm{m}$. Corte transversal do caule, parênquima com inclusões amilíferas e clorofilianas. 2D) Barra $=50 \mu \mathrm{m}$. Corte longitudinal do caule. 1. endoderme com conteúdo celulare estrias de Caspary, 2. periciclo, 3. célula crivada do floema, 4. traqueídes do xilema. 2E) Barra $=50 \mu \mathrm{m}$. macerado do caule. Esclerênquima com pontoações.

nas folhas, de forma escassa. De acordo com Fahn \& Cutler (1992), algumas epífitas que crescem em florestas tropicais possuem características xeromórficas, apresentando escamas foliares que absorvem água. Seria interessante pesquisar se as escamas caulinares de M. squamulosa, que também tem hábito epifítico, não desempenham função similar.

O extrato de caule/raízes de $M$. squamulosa apresentou cor marrom-esverdeado, odor característico, desagradável e sabor adstringente. A análise fitoquímica revelou a presença de compostos fenólicos, como taninos e flavonóides. Os taninos possuem ação protetora da mucosa, devido ao seu caráter adstringente e possivelmente seriam responsáveis por uma ação antiúlcera local, devido ao caráter adstringente presente. Os flavonóides poderiam também ser os responsáveis pela atividade antiúlcera, uma vez que aumentam a resistência dos vasos e alguns apresentam ação antiúlcera e antiinflamatória (Cristoni \& Magistrelli, 1987; Martin et al., 1988; Pathak et al., 1991).

A utilização da cromatografia muitas vezes é necessária, principalmente se duas espécies possuem uma grande semelhança quando analisadas ao microscópio ou quando se está na presença de extratos vegetais, situação em que a análise morfo-histológica torna-se impossível. Nestes casos, a cromatografia é um método eficiente, pois dificilmente duas espécies têm exatamente os mesmos constituintes químicos, e se por ventura tiverem, provavelmente não terão iguais quantidades destas substâncias (Oliveira et al., 1991). A obtenção do perfil cromatográfico também pode auxiliar a investigação de contaminantes da droga vegetal, por 

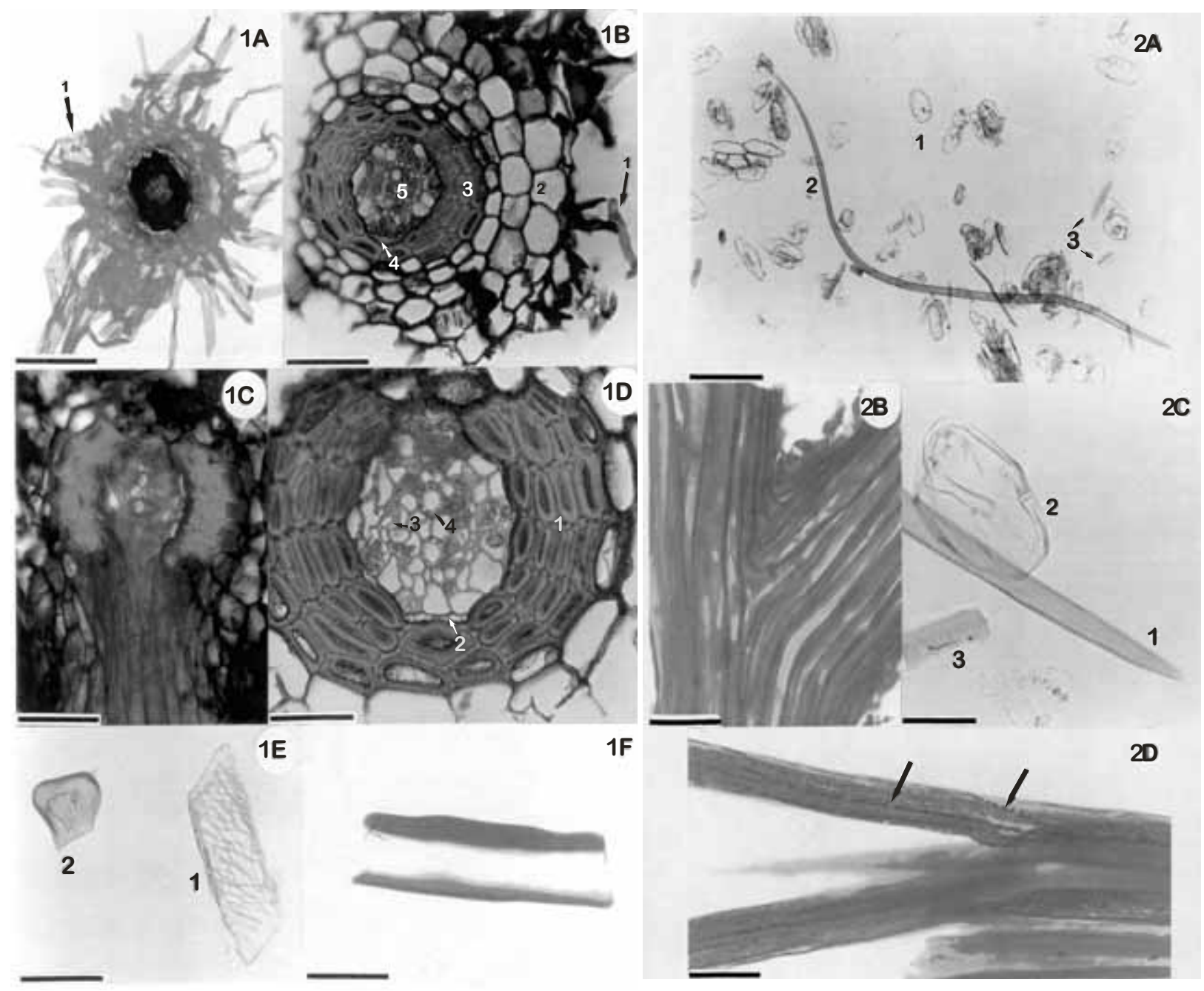

Figura 3. 1A) $B a r r a=200 \mu \mathrm{m}$. Corte transversal de raiz, altura do ápice. 1. tricomas. 1B) $B a r r a=100 \mu \mathrm{m}$.

Corte transversal de raiz, altura da base, visão geral. 1. tricomas, 2. parênquima, 3. esclerênquima, 4. endoderme, 5. feixe vascular. 1C) Barra $=100 \mu \mathrm{m}$. corte transversal de ramificação da raiz. 1D) Barra $=50 \mu \mathrm{m}$. Corte transversal de raiz. 1. esclerênquima, 2. endoderme, 3. floema, 4. xilema. 1E) Barra $=50 \mu \mathrm{m}$. macerado de raiz. 1. célula parenquimática do "córtex", 2. célula parenquimática do feixe vascular. $1 \mathrm{~F}) \mathrm{Barra}=50 \mu \mathrm{m}$. macerado de raiz, célula esclerenquimática. 2A) Barra $=500 \mu \mathrm{m}$. macerado do caule. 1. células parenquimáticas, 2. traqueíde, 3. esclereides. 2B) Barra $=200 \mu \mathrm{m}$. macerado do caule. Bifurcação do feixe vascular, que formará traços foliares ou radiculares. 2C) Barra=100 $\mu \mathrm{m}$. macerado do caule. 1 . traqueíde, 2. célula parenquimática, 3. esclereide. 2D) Barra $=50 \mu \mathrm{m}$. macerado do caule. Áreas crivadas do floema.

exemplo, algum outro órgão da mesma planta que não pertença à droga vegetal. Para auxiliar esta análise, foi apresentado, na figura 4, o perfil cromatográfico do extrato bruto de caule/raízes e suas frações, assim como da folha, um possível contaminante da droga vegetal analisada.

O trabalho realizado evidenciou que estudos morfo-histológicos são importantes tanto para a identificação da planta como da droga vegetal e o perfil cromatográfico fornece um parâmetro comparativo visando confirmar a identidade e pureza do seu extrato. As duas técnicas de análise sugeridas neste trabalho - a análise morfo-histológica e a obtenção do perfil cromatográfico do extrato bruto de caule/raízes - são de baixo custo e de rápida execução em ambientes laboratoriais de Farmácias ou Indústrias Farmacêuticas, quando houver a necessidade de se analisar droga em pó e fitoterápico.

Uma vez que o extrato bruto de caule/raízes de erva silvina e suas frações derivadas apresentaram atividade antiúlcera significante, outros estudos farmacológicos e toxicológicos devem ser feitos a fim de que o potencial fitoterápico do extrato seja avaliado em maior profundidade.

\section{AGRADECIMENTOS}

Os autores agradecem à Fapesp (projeto 1999/05904-6) pelo auxílio. 

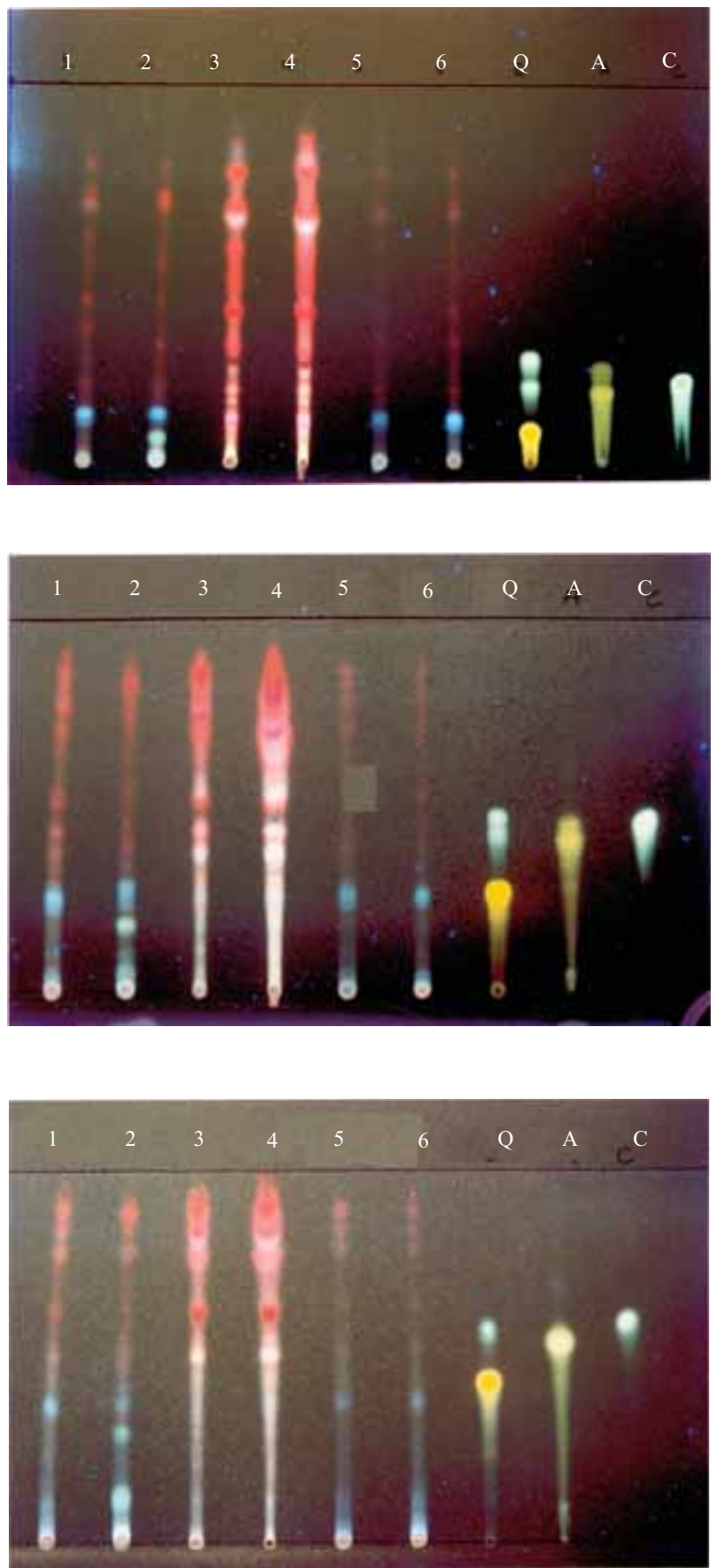

Figura 4. Perfil cromatográfico em três diferentes sistemas, onde 1=extrato bruto de caule/raízes, $2=$ extrato bruto da folha, $3=$ fração clorofórmio, 4=fração acetato de etila, 5=fração etanol, 6=fração etanol+água 1:1, $\mathrm{Q}=$ quercetina, $\mathrm{A}=$ apigenina, $\mathrm{C}=$ canferol.

\section{REFERÊNCIAS}

Arai Y, Hirohara M, Ageta H, Hsu HY 1992. Fern constituents: two new triterpenoid alcohols with mono- and bi- cyclic skeletons, isolated from Polypodioides formosana. Tetrahedron Lett 33: 1325-1328.

Banerjee RD, Sen SP 1980. Antibiotic activity of Pteridophytes. Econ Bot 34: 284-298.

Bresciani Lf, Priebe JP, Yunes RA, Dal Magro J, Delle Monache F, De Campos F, De Souza MM, CechinelFilho V 2003. Pharmacological and phytochemical evaluation of Adiantum ceneatum growing in Brazil. Z Naturforsch 58c: 191-194.

Camps F, Coll J, Marco MP, Tomás J 1990. Efficient determination of phytoecdysteroids fromajuga species and Polypodium vulgare by high-performance liquid chromatography. J. Chromatogr 514: 199-207.

Caula SA, Secchiari S, Coussio JD 1990. Polypodium phyllitidis L. (Polypodiaceae): un helecho con elevada concentración de sacarosa. Acta Farm Bonaerense 9: 111-114.

Costa AF 1972. Farmacognosia. 2 ed., 3v. Lisboa: Calouste Gulbenkian.

Cristoni A, Magistrelli MJ 1987. Antiulcer and healing activity of Vaccinium myrtillus anthocianosides. Farmaco 42: 30-43.

Fahn A 1982 Plant anatomy. 3 ed. Oxford: Pergamon Press.

Fahn A, Cutler DE 1992. Xerophytes. Berlin: Gebrüder Borntraeger. $176 \mathrm{p}$.

Farmacopéia dos Estados Unidos do Brasil 1959. 2 ed. São Paulo: Siqueira.

Font Quer P 1979. Diccionario de Botánica. 7 reimpr. Barcelona: Editorial Labor.

Gaur RD, Bhatt BP 1994. Folk utilization of some pteridophytes of deoprayag area in Garhwall Himalaia: India. Econ Bot 48: 146-151.

Huang YL, Yeh PY, Shen CC, Chen CC 2003. Antioxidant flavonoids from the rhizomes of Helminthostachys zeylanica. Phytochemistry 64: 1277-1283.

Imperato F 1990. Two mangiferin glycosides from Asplenium adiantum-nigrum. Am Fern J 80: 27-29.

Jeffrey EC 1917. The anatomy of woody plants. Chicago: University of Chicago Press.

Joly AB 1966. Botânica, introdução à taxonomia vegetal. São Paulo: Companhia Editora Nacional.

Jones DL 1987. Encyclopaedia of ferns: an introduction to ferns, their structure, biology, economic importance, cultivation and propagation. Portland: Timber Press.

Kraus JE, Sousa HC, Rezende MH, Castro NM, Vecchi C, Luque R 1998. Astra blue and basic fuchsin double staining of plant materials. Biotec Histochem 73: 235-243.

Kraus JE, Arduin M 1997. Manual básico de métodos em morfologia vegetal. Seropédica: EDUR.

Kraus JE, Montenegro G, Kim AJ 1993. Morphological studies on entomogenous stem galls of Microgramma squamulosa (Kauf.) Sota (Polypodiaceae). Am Fern J 83: 120-128.

Marco MP, Sánchez-Baeza FJ, Camps F, Coll J 1993. Phytoecdysteroid analysis by high-performanceliquid chromatography-thermospray mass spectrometry. $J$ Chromatogr 641: 81-87.

Martin MJ, Alarcón De La Lastra C, Marhuenda E, Delgado F 1988. Antiulcerogenicity of the flavonoid fraction from Dittrichia viscosa (L.) W. Greuter in rats. Phytother Res 2: 183-186.

Ogura Y 1972. Comparative anatomy of vegetative organs of the pteridophytes. In Encyclopedia of Plant Anatomy. Vol 3. Berlin: Gebrüder Borntraeger.

Oliveira F, Akisue G, Akisue MK 1991. Farmacognosia. São Paulo: Atheneu.

Ortega F, Diaz W 1993. Ethnopharmacological notes on two Venezuelan Asplenium. Am Fern J 83: 71 
Pathak D, Pathak K, Singla AK 1991. Flavonoids as medicinal agents recent advantages. Fitoterapia 62: 371-389.

Raven PH, Evert RF, Eichhorn SE 2001. Biologia Vegetal. 6 ed. Rio de Janeiro: Guanabara Koogan.

Sehnem A 1970. Flora Ilustrada Catarinense, Itajaí: Herbário "Barbosa Rodrigues".

Sota ER 1960. Opera Lilloana V. Polypodiaceae y Grammitidaceae argentinas.

Suffredini IB, Bacchi EM, Sertiè JAA 1999. Antiulcer action of Microgramma squamulosa (Kaulf.) Sota. J Ethnopharmacol 65: 217-23.

Tryon RM, Tryon AF 1982. Ferns and allied plants: with special reference to tropical America. New York: Springer-Verlag.

Tsuzuki K, Ohashi A, Arai Y, Masuda K, Takano A, Shiojima K, Ageta H, Cai SQ 2001. Triterpenoids from Adiantum caudatum. Phytochemistry 58: 363-367.

Wagner H, Bladt S 1996. Plant drug analysis. 2 ed. Berlin: Springer Verlag.

Wichtl M 1971. Die pharmakognostisch-chemische analyse. Frankfurt am Maim: Akad. Verlagsgesellschaft

Zhou TS, Ye WC, Wang ZT, Che CT, Rong-Han Zhou, Xu GJ, Xu LS 1998. Beta-carboline alkaloids from Hypodematium squamuloso-pilosum. Phytochemistry 49: 1807-1809. 